\title{
FOGYASZTÓI PREFERENCIÁK VIZSGÁLATA A NÖVÉNYI ALAPÚ TÁPLÁLKOZÁSSAL KAPCSOLATBAN
}

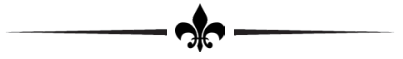

\section{EXAMINATION OF CONSUMER PREFERENCES IN RELATION TO PLANT-BASED DIET} \\ Debreceni Egyetem, Gazdaságtudományi Kar, Marketing és Kereskedelem Intézet \\ (University of Debrecen, Faculty of Economics and Business, Institute of Marketing and Commerce) \\ H-4032 Debrecen, Böszörményi út 138. \\ e-mail: mark.szakaly@gmail.com
}

\begin{abstract}
al Today, non-communicable, chronic diseases have become the number one causes of death worldwide. But while the problem is receding in developed, more civilized countries, the so called civilization diseases have shifted towards less developed societies, thus spreading throughout the world. One of the main sources of the problem is unhealthy nutrition, so compiling the right diet can reduce the spread and severity of chronic diseases. Within the framework of this article, we deal with plant-based nutrition and its characteristics. Our aim was to get to know the motivations and opinions of those who consider themselves (to be) vegetarian, and to a lesser extent those of the omnivorous groups in relation to plant-based (vegetarian) diets. One of our main findings was that vegetarians follow a plant-based diet primarily for physical and mental health, with almost two-thirds strictly adhering to their diet and the price level of which they do not consider more expensive than the omnivorous diet. Another important result was that the majority of those who followed a plant-based diet declared their diet to be healthy and themselves to be health-conscious. Based on the results, it can be stated that the followers of plant-based diet are very satisfied with their own diet.
\end{abstract}

KuLCSSZAVAK: növényi alapú; vegetáriánus; nem fertőző, krónikus betegségek; étrend; transzteoretikus modell; TTM; étrendi motivációk; döntően növényi alapú

JEL-KóDoK (JEL CODES): I10, I12

DOI: https://doi.org/10.20494/TM/8/1/1

\section{Bevezetés - INTROdUCTION}

Az elmúlt néhány évtizedben negatív jelenséggé nőtte ki magát a civilizációs betegségek terjedése a világon, megjelenésük elsősorban a fejlettebb országokhoz volt köthető korábban. Ám megfigyelhető, hogy mára a folyamat a fejlett országokban lelassult vagy néhány esetben csökkenőben van, ezzel egy időben pedig a fejlődő országokban egyre jelentősebb problé-
KEYWORDS: plant-based; vegetarian; non-communicable, chronic diseases; diet; transtheoretical model; TTM; dietary motivations; predominantly plant-based

mává válik. Az egészségtelen táplálkozás a nem fertőző betegségek, például a szívkoszorúér-betegség, agyvérzés, szívelégtelenség és a rák esetében módosítható kockázati magatartást jelent (BECHTHOLD et al., 2019; KEY et al., 2002; LAVIE et al., 2009). Ezenkívül az epidemiológiai tanulmányokat áttekintve CENA és CALDER (2020) arra a következtetésre jutottak, hogy az egészséges étrend követése és betartása csökkenti a nem fertőző civilizációs 
betegségek kockázatát.

Napjainkban az egészségmegőrzés és az élelmiszerfogyasztás elengedhetetlen része lett az egészséges táplálkozás, és az egészség, mint tényező (VOSSEN és REINHARDT, 2002; RÜTZLER és KIRIG, 2007), mely egyre nagyobb fontossággal bír, és egyenesen megatrend lett belőle. Az egészségtudatosság fogalmát pedig míg korábban csak a „trendi” szóval lehetett jellemezni, mára egyértelmü trenddé nőtte ki magát, mely azt jelenti, hogy egyre többen és többször figyelnek oda testsúlyukra és arra, hogy mit esznek (GFK, 2016). Az egészségtudatosság immáron befolyásolja a fogyasztói magatartást is, melynek következtében az egészség már nem csak érték, de elvárás is lett. A megnövekedett tudatosság és felelősség következtében (DAGEVOS és GAASBEEK, 2001) bizonyos jellegú termékek vásárlásához hajlandóak vagyunk egyre nagyobb anyagi áldozatot is hozni (TÖRÖCSIK, 2011).

$\mathrm{Az}$ egészségtudatos táplálkozás egyik formája lehet a növényi alapú (mely fogalmat jelen cikk keretei között a vegetáriánus szó szinonimájaként fogjuk kezelni) étrendek követése. A legtöbben a vegetáriánus táplálkozást öszszekapcsolják az egészségmegőrzéssel és a betegségek megelőzésével. Másképpen kifejezve: általánosságban úgy vélik, hogy a megfelelően tervezett vegetáriánus étrend megfelelő táplálkozási és egészségügyi előnyöket jelenthet fogyasztója számára, különösen a krónikus, nem fertőző betegségek kockázatának csökkentésében (MELINA et al., 2016). E fontos szempont a vegetarianizmus kapcsán gyakran fordul elő mind tudományos közlemények, mind újságcikkek keretei között is.

Jelen tanulmány célja egy 2019 júniusában Magyarországon készült 319 fős, nem reprezentatív kutatás bemutatása, mely abból a szempontból hiánypótló, hogy hazánkban még viszonylag gyerekcipőben jár a vegetáriánusok életmód-, táplálkozás- és attitűdbeli vizsgálata mind az elmélet, mind a gyakorlat szintjén. Becslések szerint fél és másfél milliárd közé tehető a vegetáriánusok száma bolygónkon (HEINRICH BÖLL STIFTUNG, 2014; LEAHY et al., 2010). Közülük mindössze 75 millióan vannak, akik saját választásuk miatt vegetáriánusok (bár ez a szám fokozatosan növekszik a növekvő gazdagság és az oktatás révén). A maradék 1450 millió vegetáriánus léte azonban választás helyett a szükségen alapul: ők a született vegetáriánusok, illetve azok, akik amint anyagilag megengedhetik maguknak, húst kezdenek enni. A vegetáriánusok száma a legmagasabb Indiában, ahol a népesség harmada vegetáriánus (LEAHY et al., 2010), a felnövekvő generációk, tehát a serdülők többsége pedig lakto-vegetáriánus (NATIONAL NUTRITION MONITORING BUREAU, 1994; NATIONAL NUTRITION MONITORING BUREAU, 2006).

A növényi alapú táplálkozás kialakulását úgy is szemlélhetjük, mint egy törzs- és evolúciós fejlődés eredményét. Megfigyelhető, hogy az élelmiszerfogyasztók gondolkodásmódjának átalakulásával megváltoztak a fogyasztói szokások és preferenciák is. Általánosságban a fogyasztói magatartás egyre inkább a tudatos, felelős fogyasztás irányába tart, mely jelenség DAGEVOS és GAASBEEK (2001) szerint egy új fogyasztói szegmenset eredményezett az eddig fennálló három csoport helyett. A szerzők szerint a fogyasztókat négy alaptípusba lehet besorolni:

1. A tradicionális fogyasztók ár- és időérzékenyek; a változásokat nehezen fogadják; a tradicionális társadalmi és kulturális értékeket keresik; kevésbé kényelmi fogyasztók; késői többség/lemaradók.

2. A kalkuláló fogyasztókra jellemző a materiális értékek keresése (hasznos, kényelmes és elérhető); elveik a hatékonyság, kiszámíthatóság; fontos számukra az ár/ érték arány és a tömegtermékek; korai/ kései többség.

3. Az egyedi fogyasztók ,én-mentalitással” rendelkeznek, így kiemelt szerepet kap az önmegvalósítás és önkifejezés; hedonisták, fontos számukra a látható/hivalkodó, modern fogyasztás és a választékosság, és jobban érdeklődnek a humoros, hóbortos termékek iránt.

4. A felelősségteljes fogyasztók a nem materiális értékeket (etika és tisztesség) keresik; egészség-, társadalom- és környezetorientáltak; fogyasztáskor és a termelésben is az átláthatóságot veszik alapul; nem hagyományos életstílus köthető hozzájuk, nevezetesen például a vegetáriánus vagy bármely más „alulfogyasztó” evési magatartás, étrend. 
És éppen a 4. kategóriában áll a vegetáriánus táplálkozás lényege: amikor erról a táplálkozási formáról beszélünk, gyakran jutnak eszünkbe az imént sorolt tulajdonságok.

\subsection{A növényi alapú táplálkozás mögött meghúzódó étrendi motivációk - Dietary Motivations Behind Plant-based Diet}

A motiváció fontos szerepet játszik az ember érzéseiben, szándékaiban és viselkedésében. $\mathrm{Az}$ étrendi motiváció különbségei - és tágabb értelemben az emberek által követett célok a későbbiekben is hatással vannak az étrendi korlátozások sikeres betartására, valamint az egészségre, illetve a testsúlyhoz kapcsolódó célok elérésének hatékonyságára (FUGLESTAD et al., 2015). A vegetáriánusok nagyobb valószínűséggel tekintenek úgy étrend-választásukra, mint identitásuk meghatározó jellemzőjére, emellett az étrendi motivációik sokszínűsége központi szerepet játszhat ezen étrendi csoportok megértésében. LEITZMANN (2014) szerint az első számú (Ruby, 2011 szerint a második számú) mozgatórugót a növekvő, egészséggel kapcsolatos aggodalmak jelentik.

Az egészség, mint elsődleges vagy másodlagos mozgatórugó szerepét támasztja alá JABS et al. (1998) korábbi elmélete is, akik szerint két fő - és ez esetben nem a növényi alapú szinonimájaként használt - vegetáriánus kategóriát lehet elkülöníteni: az egészségorientált és az etikai vegetáriánusokat. Mindenekelőtt kijelenthetjük, hogy az első csoport kisebb, az utóbbi nagyobb valószínüséggel tér át a szigorúbb vegán étrendre. Tekintettel az egészségügyi és etikai motivációk nagyon eltérő jellegére, az egyik a saját, a másik pedig mások jólétére összpontosít. Az egészségorientált vegetáriánusok növényi étrendjüket a lehetséges nehézségek miatt aggódva akceptálták, és elsősorban az étrendjük megváltoztatásának különféle előnyeire és akadályaira koncentráltak. Ezzel szemben az etikai vegetáriánusok állatjóléti okokból fogadták el vegetáriánus étrendjüket, elsősorban az erkölcsi szempontok- ra összpontosítva. Ók hajlamosak voltak a növényi étrend hirtelen elfogadására, a húsevést undorral és érzelmi szorongással társítva, és csökkentve ezt a szorongást azáltal, hogy öszszhangot teremtenek az étrendjük és az állatok jólétével kapcsolatos hitük között.

A két fő kategória mellett (melyekről kutatásunkban mi is említést tettünk), számos egyéb szempont is fellelhetô a szakirodalomban (pl. VÉHA et al., 2019b; FEHÉR et al., 2020) a vegetáriánus lét mellett - általában az állatokkal (mint állatok nevelése és levágása (FOX és WARD, 2008)), az egészséggel, az ökológiával, a vallással kapcsolatos aggodalmak vagy ezen motivációk valamilyen kombinációja a vezérlő elv (PLANTE et al., 2019). A gyakran közölt okok között szerepelnek még a hús iránti undor (RUBY, 2012), a fogyás iránti vágy, az ízlésbeli preferenciák, a pénzmegtakarítás és a politikai kérdések is (HOFFMAN et al., 2013). Nem elhanyagolható szempont az sem, hogy sokan abból a célból térnek át erre a táplálkozási formára, hogy egy adott társadalmi csoporthoz tartozzanak. Ez a szociális identitás motivációja (PLANTE et al., 2019). Egyéb szerzők is szociális identitásként hivatkoznak a vegetarianizmusra (pl. HORNSEY és JETTEN, 2003; ROSENFELD és BURROW, 2017; ROSENFELD, 2018; ROTHGERBER, 2017; NEZLEK és FORSTELL, 2020).

A növényi alapú étrendet hátráltató tényezőkre szintén találunk utalást a szakirodalomban (pl. VÉHA et al., 2019a; FEHÉR et al., 2020).

\section{ANYAg ÉS MÓDSZER - MATERIAL AND METHOD}

A cikk elkészítése során szekunder és primer kutatásokat végeztünk annak érdekében, hogy feltárjuk a különböző táplálkozási módokkal kapcsolatos fogyasztói preferenciákat, szokásokat és attitűdöket. 


\subsection{A szekunder és primer piackutatás általános jellemzői - General Characteristics of Secondary and Primary Market Research}

A munkát a meglévő szakirodalom és a szekunder piackutatások eredményeinek feldolgozásával kezdtük, ami azt jelenti, hogy másodkézből szereztük meg a szükséges információkat. A már rendelkezésre álló adatokat összegyüjtöttük, rendszereztük és újraértelmeztük. Ehhez különböző könyveket, tudományos folyóiratokat, sajtóanyagokat, piackutató cégek felméréseit, illetve internetes forrásokat használtunk fel.

A primer piackutatás során kvantitatív online kérdőíves megkérdezést alkalmaztunk 317 fő bevonásával. A felmérés során ötfokozatú skála típusú, valamint eldöntendő és több válaszlehetőséget biztosító kérdéseket is alkalmaztunk. A kérdőív végén a háttérváltozók következtek, amelyek a válaszadó nemére, életkorára, családi állapotára, a háztartás havi nettó jövedelmére, a település lakosainak számára, és a legmagasabb iskolai végzettségére vonatkoztak. A megkérdezés teljes mértékben online felületen zajlott, a mintavétel nem tekinthető reprezentatívnak. A minta kiválasztása nem volt véletlenszerü, a legtöbb kitöltés esetében hólabda módszert alkalmaztunk, vagyis a válaszadók egymást ajánlották, így sikerült minél szélesebb válaszadó körhöz eljutni.

A mintavétel során a Google Drive online ürlapszerkesztő programot használtuk, amely a kérdőív szerkesztése befejeztével egy linket generált. A kapott linket közösségi portálon (Facebook) terjesztettük. A Facebook-on az ismerőseinket arra kértük, hogy saját ismerőseiket is kérjék meg a kérdőív kitöltésére. A kérdőívek kitöltetésére 2019. január 30. és 2019. március 15. között került sor.

A kapott eredményeket SPSS és MS EXCEL programok segítségével dolgoztuk fel. A statisztikai elemzések közül a gyakorisági megoszlások, a kereszttáblázatos elemzések (khi-négyzet próbával), illetve átlag- és szórásszámítások kerültek alkalmazásra.

\subsection{Az alkalmazott kérdóív és a minta szocio-demográfiai jellemzői - Applied Questionnaire and Socio- demographic Characteristics of the Sample}

A kérdőív a következő kérdésblokkokat tartalmazta:

- Általános élelmiszerfogyasztás (egyes élelmiszerkategóriák fogyasztási gyakorisága; információforrások jelentősége; a válaszadók kategorizálása növényi, illetve állati eredetű táplálkozási mód alapján).

- A döntően állati alapú étrendet folytatók preferenciái (az állati eredetű élelmiszerfogyasztás indokai; az állatiról a növényi eredetű táplálkozásra történő áttérés indokai; alternatív táplálkozási módok ismerete; legszimpatikusabb táplálkozási módok; az állati és a növényi alapú táplálkozás költségeinek összehasonlítása; az egészséges táplálkozásra történő áttérés szakaszai; a növényi alapú táplálkozás hátrányai).

- A döntően növényi alapú étrendet folytatók preferenciái (a növényi eredetű élelmiszerfogyasztás indokai; alternatív táplálkozási módok ismerete; a legszimpatikusabb táplálkozási módok; a válaszadók kategorizálása növényi alapú táplálkozási mód szerint; az állati és a növényi alapú táplálkozás költségeinek összehasonlítása; konzekvens magatartás elemzése a növényi alapú táplálkozás szabályainak betartása terén; az áttérés esélyei a növényi alapúról az állati eredetű táplálkozásra; az egészséges táplálkozásra történő áttérés szakaszai).

- Felhasznált információforrások (a jelenleg igénybe vett információforrások típusai; leghitelesebb információforrások; információforrások igénybevétele a jövőben).

A kérdőívet az ún. szocio-demográfiai háttérváltozók zárták, a személyes jellemzőket a 1/A. és az 1/B. táblázat foglalja magában. Fontos kiemelni, hogy jelen kutatás csak a kérdőívben szereplő kérdések egy részét tartalmazza. 
Az utóbbi kategóriával kapcsolatos kérdések így értelemszerűen jóval kevesebbszer szerepelnek majd. Emellett a továbbiakban - a nemzetközi szakirodalom nagy részének mintájára - a két állati eredetű étrendet fogyasztó csoportot (akik étrendje nagyarányú húsfogyasztást is feltételez), egységesen mindenevőknek fogjuk nevezni, míg a döntően növényi étrendet követők két csoportját vegetáriánus elnevezéssel illetjük majd.

A minta megoszlása háttérváltozók szerint (Distribution of the Sample by Background Variables) $(\mathrm{N}=\mathbf{3 1 7})$

\begin{tabular}{|c|c|c|}
\hline \multirow{2}{*}{ Megnevezés (Label) } & \multicolumn{2}{|c|}{ A minta megoszlása (Sample distribution) } \\
\hline & Fó (count) & $\%$ \\
\hline \multicolumn{3}{|c|}{ Összes megkérdezett (Total number of respondents) } \\
\hline Összesen (Total) & 317 & 100,0 \\
\hline \multicolumn{3}{|c|}{ Nemek (Gender) } \\
\hline Férfi (Men) & 92 & 29,0 \\
\hline Nő (Women) & 225 & 71,0 \\
\hline \multicolumn{3}{|c|}{ Életkor (Age) } \\
\hline 18-25 éves (18-25 years) & 37 & 11,7 \\
\hline 26-35 éves (18-25 years) & 65 & 20,5 \\
\hline 36-45 éves (36-45 years) & 93 & 29,3 \\
\hline 46-55 éves (46-55 years) & 70 & 22,1 \\
\hline 56 éves és idősebb (56 years and older) & 52 & 16,4 \\
\hline \multicolumn{3}{|c|}{ Családi állapot (Marital status) } \\
\hline Házas (Married) & 165 & 52,1 \\
\hline Élettárssal él (Lives with a partner) & 54 & 17,0 \\
\hline Nőtlen/Hajadon (Unmarried/Single) & 63 & 19,9 \\
\hline Elvált (Divorced) & 23 & 7,3 \\
\hline Özvegy (Widow) & 6 & 1,9 \\
\hline Külön él házastársától (Lives separately from his spouse) & 6 & 1,8 \\
\hline \multicolumn{3}{|c|}{ Iskolai végzettség (Education) } \\
\hline Maximum 8 általános (Elementary school) & 2 & 0,6 \\
\hline Szakmunkás (Vocational school) & 2 & 0,6 \\
\hline Érettségi (High school degree) & 49 & 15,5 \\
\hline Felsőfokú diploma (Higher education degree) & 264 & 83,3 \\
\hline \multicolumn{3}{|c|}{ Az élelmiszer-beszerző személye (Shopping person) } \\
\hline Elsődleges beszerző (Primary shopper) & 234 & 73,8 \\
\hline Nem elsődleges beszerző (Non-primary shopper) & 83 & 25,2 \\
\hline
\end{tabular}

Forrás (Source): Saját szerkesztés (Authors'own compilation) 
A minta megoszlása háttérváltozók szerint (Distribution of the Sample by Background Variables) $(\mathrm{N}=\mathbf{3 1 7})$

\begin{tabular}{|c|c|c|}
\hline \multirow{2}{*}{ Megnevezés (Label) } & \multicolumn{2}{|c|}{ A minta megoszlása (Sample distribution) } \\
\hline & Fö (count) & $\%$ \\
\hline \multicolumn{3}{|c|}{ Szubjektív jövedelemérzet (Subjective income) } \\
\hline $\begin{array}{l}\text { Nagyon jól megél(nek) belóle és félre is tud(nak) tenni (Can live on } \\
\text { it very well and can also save) }\end{array}$ & 108 & 34,1 \\
\hline $\begin{array}{l}\text { Megél(nek) belőle, de keveset tud(nak) félre tenni (Can live on it } \\
\text { but can save little) }\end{array}$ & 149 & 47,0 \\
\hline $\begin{array}{l}\text { Éppen elegendő, de félretenni már nem tudnak (Just enough to live } \\
\text { on but cannot save) }\end{array}$ & 38 & 12,0 \\
\hline $\begin{array}{l}\text { Néha arra se nagyon elég, hogy megéljen(ek) belóle (Sometimes } \\
\text { cannot make ends meet) }\end{array}$ & 3 & 0,9 \\
\hline Nem tudja/nem válaszol (Not known/No answer) & 19 & 6,0 \\
\hline \multicolumn{3}{|c|}{ Az egészségtudatosság mértéke (The degree of health awareness) } \\
\hline Egyáltalán nem egészségtudatos (Not health-conscious at all) & 4 & 1,3 \\
\hline Többnyire nem egészségtudatos (Mostly not health-conscious) & 27 & 8,5 \\
\hline Egészségtudatos is, meg nem is (Both health-conscious and not) & 92 & 29,0 \\
\hline Többnyire egészségtudatos (Mostly health-conscious) & 167 & 52,7 \\
\hline Nagyon egészségtudatos (Very health-conscious) & 26 & 8,2 \\
\hline Nem tudja/nem válaszol (Not known/No answer) & 1 & 0,3 \\
\hline \multicolumn{3}{|c|}{ A környezettudatosság mértéke (The degree of environmental awareness) } \\
\hline $\begin{array}{l}\text { Egyáltalán nem környezettudatos (Not environmentally conscious } \\
\text { at all) }\end{array}$ & 1 & 0,3 \\
\hline $\begin{array}{l}\text { Többnyire nem környezettudatos (Mostly not environmentally } \\
\text { conscious) }\end{array}$ & 27 & 8,5 \\
\hline $\begin{array}{l}\text { Környezettudatos is, meg nem is (Both environmentally conscious } \\
\text { and not) }\end{array}$ & 58 & 18,3 \\
\hline Többnyire környezettudatos (Mostly environmentally conscious) & 181 & 57,1 \\
\hline Nagyon környezettudatos (Very environmentally conscious) & 49 & 15,5 \\
\hline Nem tudja/nem válaszol (Not known/No answer) & 1 & 0,3 \\
\hline
\end{tabular}

\section{EREDMÉNYEK ÉS ÉRTÉKELÉSÜK - REsults AND Discussion}

Ebben a fejezetben a primer kutatás eredményeit ismertetjük. A kutatás keretei között nem az összes, de egyes szempontok alapján összehasonlító elemzés keretében - vizsgáltuk a döntően növényi alapon táplálkozókat (azaz a magukat már vegetáriánusnak vallókat) és a döntően állati alapon táplálkozókat (akikkel többnyire „mindenevők” néven találkozhatunk a kapcsolódó szakirodalomban).

\subsection{A különböző étrendi kategóriákba} tartozó válaszadók aránya Proportion of Respondents Belonging to Different Dietary Categories

A téma bemutatása előtt fontos ismertetni, hogy a válaszadók milyen arányban tartoztak a különböző étrendi csoportokba. A felmérésben két-két mindenevő és vegetáriánus kategórián belül négy étrendi csoportot különböztettünk meg, amelyek a következők:

1. Teljes mértékben növényi étrendet folytatók (szigorú vegetáriánusok). 
2. Teljes mértékben állati (hús, tej, tojás) étrendet folytatók (szigorú mindenevők).

3. Inkább növényi étrendet folytatók (megengedő vegetáriánusok).

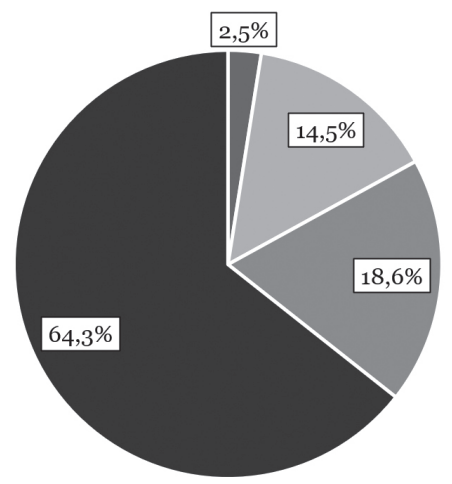

1. ÁBRA

4. Inkább állati (hús, tej, tojás) étrendet folytatók (megengedő mindenevők).

A négy csoport megoszlását a mintában az 1. ábra szemlélteti.

A különböző étrendi csoportokba tartozók aránya (Proportion of People Belonging to Different Dietary Groups) (N=317)

Forrás (Source): Saját szerkesztés (Authors'own compilation)

A kérdőívben két-két mindenevő és vegetáriánus kategóriát különítettünk el, egyéni észlelés alapján. A legkisebb arányban a teljes egészében növényi étrenden élők voltak, mindössze 2,5\%-nyian. Ők azok, akiknek az étrendje gyakorlatilag semmilyen átfedésben nincs a mindenevők étrendjével. Jóval többen, 18,6\%-nyian voltak az 'Inkább növényi' kategóriába tartozók, akiknél elfogadott, hogy néha „bünöznek”, azaz vagy húst vagy állati eredetü tápanyagokat is fogyasztanak, vegetáriánus kategóriától függően. Így tehát a vegetáriánusok összesen 21\%-os részarányt képviselnek a mintán belül. A húsevők vagy mindenevők aránya 79\%-os volt. Ôk azok, akik saját identitásukat már nem sorolják a vegetáriánusok közé még akkor sem, ha sok növényi táplálékot fogyasztanak. Márpedig ebben a témában valójában csak az adott személy önmeghatározására, identitására támaszkodhatunk, objektíven nehéz mérni, mikortól számít valaki vegetáriánusnak.

A háttérváltozókra végzett kereszttáblás elemzés során több esetben is szignifikáns kapcsolatot találtunk. A teljes mértékben állati (19,6\%) és az inkább állati eredetű termékek fogyasztása $(69,6 \%)$ a férfiakra jobban jellemző, mint a nőkre. Ebből logikusan adódik, hogy a női válaszadók között nagyobb arányban találhatók a teljes mértékben növényi $(2,7 \%)$ és az inkább növényi tápanyagokkal táplálkozók (22,7\%), mint a férfiak körében $(\mathrm{p}=0,021)$. A többi háttérváltozó esetében nem volt kimutatható szignifikáns kapcsolat.

\subsection{A növényi alapú táplálkozás árszínvonala a vegetáriánusok és a mindenevók szerint - The Price Level of Plant-based Diet According to Vegetarians and Omnivores}

A 2. ábrán látható a döntően állati, a 3. ábrán pedig a döntően növényi alapon táplálkozók véleményének megoszlása aszerint, hogy saját észlelésük alapján mennyibe kerülhet egy növényi alapú étrend követése. 
Több pénzbe kerül a növényi alapú táplálkozás? (Does plant-based nutrition cost more money?)

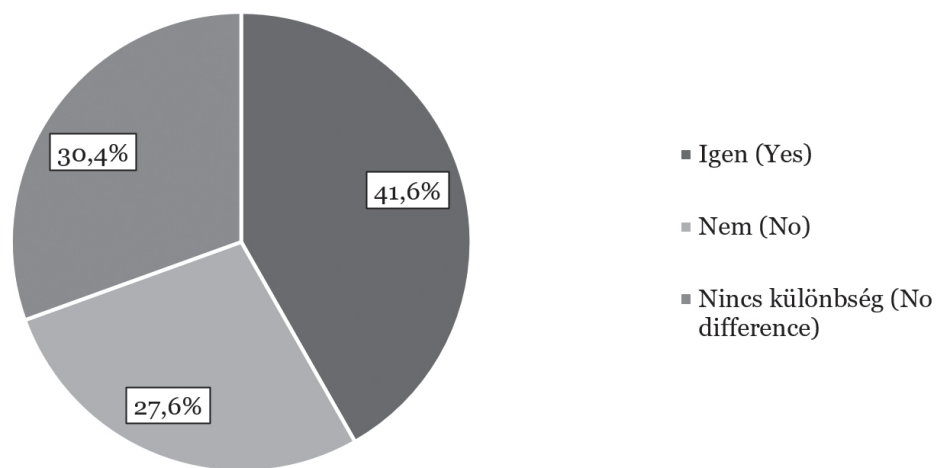

2. ÁBRA

FIG. 2

A növényi alapú táplálkozás észlelt költsége a döntően állati eredetú étrendet folytatók csoportjában (Perceived Cost of Plant-based Diet in the Group of those with a Predominantly Animal-based Diet) $(\mathrm{N}=\mathbf{2 5 0})$

Forrás (Source): Saját szerkesztés (Authors'own compilation)

\title{
Több pénzbe kerül a növényi alapú táplálkozás? (Does plant-based nutrition cost more money?)
}

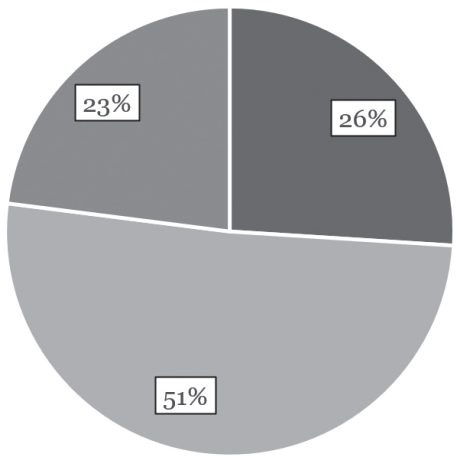

\author{
- Igen (Yes) \\ = Nem (No) \\ - Nincs különbség (No \\ difference)
}

3. ÁBRA

A növényi alapú táplálkozás észlelt költsége a döntően növényi alapon táplálkozók csoportjában (Perceived Cost of Plant-based Nutrition in the Group of Predominantly Plant-based Dieters) $(\mathrm{N}=67)$

Forrás (Source): Saját szerkesztés (Authors'own compilation)

A két ábra jelentős eltéréseket mutat a növényi alapú étrendek észlelt árszínvonalát illetően: míg a vegetáriánusok több mint fele állítja, hogy nem drágább a növényi étrend, addig a mindenevők csaknem fele (41,6\%) ennek éppen az ellenkezőjét gondolja. Összességében a növényi alapon táplálkozók háromnegyed része állítja, hogy a növényi étrend nem kerül többe fogyasztójának, ami nyilván arra a számos szakértő által is hangoztatott állításra utal, miszerint kulcsfontosságú a jól összeállított vegetáriánus étrend - azaz, sok szempontból nagyon eltérőek lehetnek a különböző növényi étrendek, elég csak a különböző zöldségek és gyümölcsök áraira gondolnunk. A mindenevők esetén ugyanez az arány jóval alacsonyabb, $58,0 \%$.

A 4. ábra a döntően növényi alapú étrendet folytatók étrendválasztási szempontjait, indokait mutatja be. 


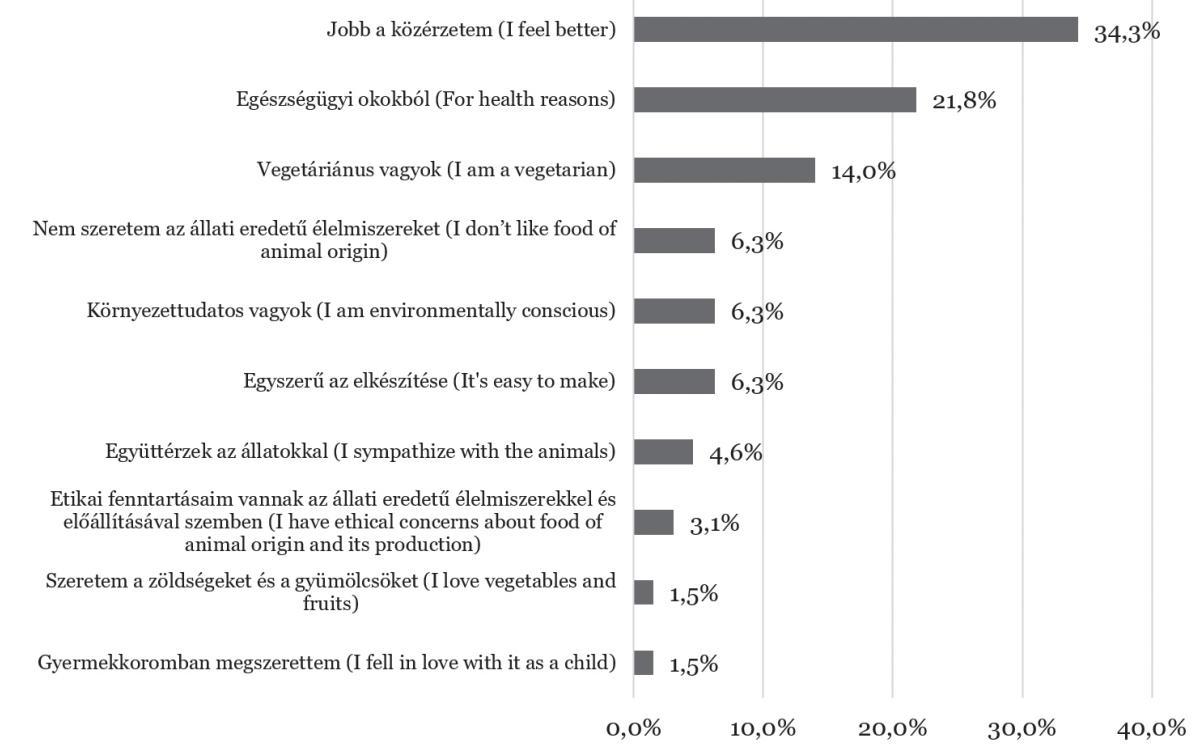

4. ÁBRA

$0,0 \% \quad 10,0 \% \quad 20,0 \% \quad 30,0 \% \quad 40,0 \%$

\section{A döntően növényi étrendet követők étrendválasztási szempontjai (Dietary Choices of those who Predominantly Follow a Plant-based Diet) $(\mathrm{N}=67)$}

Forrás (Source): Saját szerkesztés (Authors'own compilation)

Ebből kiderül, hogy az étrendválasztás legdominánsabb szempontjai a jobb közérzet megteremtése, illetve az egészségügyi indokok, ami leginkább a testi jóllétet jelenti. A válaszadók 14\%-a azzal indokolta étrendjét, hogy vegetáriánus, ami jelen esetben azt jelenti, hogy az illetônek ez az állapot teljesen természetes, el sem tudja képzelni, hogy húst egyen. Ők a „született vegetáriánusok”, akik másfajta étrendet tulajdonképpen nem tapasztaltak meg, így véleményt sem tudnak igazán formálni, szemben azokkal, akik ismerik a húsevő (mindenevő) étrend minden előnyét és hátrányát. Ennek feleltethető meg a következő csoport, akik egyszerüen nem szeretik az állati eredetü táplálékokat, ők kiábrándultságból váltottak erre az étrendre.

Összeadva, magas részarányt képviselnek a morális („Együttérzek az állatokkal”), a környezeti („Környezettudatos vagyok”) és az etikai („Etikai fenntartásaim vannak...”) megfontolások (14\%) a vegetáriánus étrend mellett. Továbbá $6,3 \%$ vallotta azt, hogy egyszerü az elkészítése, ez a fő indok, míg a legfelső két válasz, a zöldségek és gyümölcsök szeretete, illetve az, hogy valaki gyerekkorában szeretett bele a növényi ételekbe, az egyéb válaszok kategóriájában szerepelt.

A férfiak 4,3\%-a, a nők 8,0\%-a jelentette ki, hogy a növényi alapú étrend fogyasztásakor jobb a közérzetük. Ezt nevezték meg a legfőbb oknak a növényi alapú étrend fogyasztásához kapcsolódóan $(\mathrm{p}=0,080)$. Az egészségügyi okokból történő növényi alapú étrend fogyasztása a nőket érinti leginkább a férfiakkal szemben $(\mathrm{p}=0,080)$. Az iskolai végzettség vonatkozásában vizsgálva a kérdést megállapítható, hogy az érettségi vagy felsőfokú végzettséggel rendelkezőknek a jobb közérzet, a náluk alacsonyabb iskolázottsági szinttel rendelkezőknek inkább az egészségügyi és az állatokkal való együttérzés a két legfőbb ok a növényi alapú étrend választása mellett $(\mathrm{p}<0,001)$.

A fentiekkel szemben a 2. táblázat a mindenevők étrendválasztási szempontjait mutatja be. 
A döntően állati termékeket fogyasztók étrendválasztási indokai (Reasons for Dietary Choices of Consumers of Predominantly Animal Products) (N=250)

\begin{tabular}{|c|c|c|}
\hline \multirow{2}{*}{ Indokok (Reasons) } & \multicolumn{2}{|c|}{$\begin{array}{c}\text { Válaszok megoszlása } \\
\text { (Distribution of responses) }\end{array}$} \\
\hline & Fö (Count) & $\%$ \\
\hline Szeretem az állati eredetủ élelmiszereket (I love food of animal origin) & 155 & 62,0 \\
\hline Teljes értékű étrendet biztosít számomra (It provides me a complete diet) & 152 & 60,8 \\
\hline $\begin{array}{l}\text { Nem tudok jóllakni a növényi alapú élelmiszerektól (I can’t get enough of plant-based } \\
\text { foods) }\end{array}$ & 59 & 23,6 \\
\hline $\begin{array}{l}\text { Mások is ezt fogyasztják a környezetemben (Others also consume it in my } \\
\text { environment) }\end{array}$ & 23 & 9,2 \\
\hline Egészségügyi okokból (For health reasons) & 23 & 9,2 \\
\hline Nem rajongok a növényi eredetủ élelmiszerekért (I’m not a fan of plant-based foods & 12 & 4,8 \\
\hline $\begin{array}{l}\text { Egy igazi magyar elsősorban állati eredetű élelmiszereket eszik (A real Hungarian } \\
\text { eats mainly food of animal origin) }\end{array}$ & 5 & 2,0 \\
\hline Egyéb válaszok (Other answers) & 10 & 4,0 \\
\hline
\end{tabular}

Ahogy a táblázatból jól kivehető, a két, döntően állati eredetű kategória fogyasztói kimagasló arányban, 61\%-nyian úgy gondolják, jelenlegi étrendjük már így is teljes értékü, tápanyagokban gazdag. De legalább ilyen fontos, hogy a túlnyomó többség az állati eredetű táplálékok (pl. hús, tej és tojás) szeretetének is köszönheti, hogy nem váltott át a növényi alapú étrendre.

Jócskán lemaradva a harmadik helyen az az állítás szerepel, hogy „nem lakok jól a növényi alapú élelmiszerektől.” Ez persze legtöbbeknél csak feltételezés lehet, hisz valószínúleg a nagy többségük nincs tisztában a vegetáriánus étrend jellemzőivel. Ugyanakkora arányban, 9-9\%-ban vallották azt, hogy a környezetük nagy befolyással bír rájuk nézve abban, hogy mindenevó étrendet folytatnak, illetve, hogy egészségügyi okok állnak a táplálkozási módjuk hátterében. Kevesen, de voltak néhányan, akik egész egyszerúen nem rajonganak ezekért az élelmiszerekért, vagy, hogy ezek távol állnak a magyarosnak definiált értékrendtől. Az egyéb válaszok között többek között olyanok szerepeltek, minthogy „testépíto étrendet könnyebb állati eredetűből összeállítani”, de a testépítésre való utalás többször is szerepelt, emellett többen is a kiegyensúlyozott, mindenevő táplálkozásra utaltak, mint ami az ember természetes életfeltétele.

A háttérváltozókra végzett kereszttáblás elemzések során megállapítható, hogy csak a fó élelmiszer-beszerzői szerep esetében mutatható ki szignifikáns kapcsolat. Ennek megfelelően, a család elsődleges bevásárlói nagyobb arányban (9,4\%) jelölték az egészségügyi okokat, mint a nem elsődleges élelmiszer beszerzők (1,2\%; p=0,013).

A következő két táblázat (3. és 4. táblázat) a „Transzteoretikus Modell (TTM) - Változás 6 szakasza" konstrukcióját szemlélteti a vegetáriánus és a mindenevő válaszadókra vonatkoztatva.

A modell állításai - mindkét fó étrendi kategória esetén - két csoportra bonthatók, és ebben az esetben különösebb arányeltolódást láthatunk: a növényevők több mint fele, 50,7\%a úgy érzi, már több mint fél éve vagy mindig is egészségesen táplálkozott. Ugyanez az arány a másik étrendi csoportban (4. táblázat) kereken $38 \%$ volt, ami azt jelenti, hogy a döntően növényi étrendet folytatók úgy érzik, egészségesebben táplálkoznak, mint döntően húsevő társaik. Érdemes visszautalnunk a 4. ábra adataira, ahol kiderült, a növényevők 21,8\%-a döntött elsősorban egészségügyi okokból étrendje mellett. Érdekesség egyébként, hogy akkor az összes válaszadó 56,1\%-a választotta elsődleges indokának a testi-lelki egészséget (jobb közérzet), ami nagyon hasonló a TTM 56,6\%-ához, ami az átállás felső három szakaszának összege. Emellett a növényevők 32,8\%-a érez erős 
késztetést és tervez lépéseket tenni az egészségesebb táplálkozás irányába (szemben a mindenevők 29,2\%-ával), és 10,4\% volt az, aki nem tervez ilyet, szemben a mindenevők 22,8\%-os részarányával, ami viszont több mint 10\%-os differencia.

A 2. táblázat adataira elvégzett kereszttáblás elemzés szignifikáns különbségeket tárt fel nem, iskolai végzettség és környezettudatosság szerint. Eszerint a női válaszadók jellemzően a fenntartási szakaszban vannak $(8,4 \%)$, tehát több mint fél éve áttértek egy általuk egészségesebbnek vélt étrendre, míg a férfiak esetében ez az arány mindössze $3,3 \%(\mathrm{p}<0,05)$. A férfi válaszadók jellemzően azt tervezik, hogy a kö- vetkező egy hónapban lépéseket fognak tenni, hogy áttérjenek egy általuk egészségesebbnek vélt táplálkozásra $(\mathrm{p}<0,05)$. A maximum 8 általánost végzettek fele még csak erős késztetést érez arra, hogy áttérjen a vizsgált étrendre, az érettségizettek legnagyobb arányban (10,2\%) a fenntartási szakaszban vannak a felsőfokú végzettséggel rendelkezőkkel együtt $(6,4 \%$; $\mathrm{p}=0,018)$. Minél magasabb a környezettudatosság mértéke egy válaszadónál, annál jellemzőbb rá, hogy a fenntartási szakaszba lép, tehát áttér a növényi alapú étrendre $(\mathrm{p}=0,030)$.

A következő két táblázatban (5. és 6. táblázat) szintén összehasonlító elemzést végeztünk.

Az egészséges táplálkozásra való áttérés szakaszai a döntően növényi alapú étrendet folytatók körében (Stages of the Transition to a Healthy Diet among those on a Predominantly Plant-based Diet $)(\mathrm{N}=67)$

\begin{tabular}{lcc}
\hline \multicolumn{1}{c}{ Válaszkategóriák (Answer categories) } & \multicolumn{1}{c}{$\begin{array}{c}\text { Válaszok megoszlása } \\
\text { (Distribution of responses) }\end{array}$} \\
\cline { 2 - 3 } & Fó (Count) & \% \\
\hline $\begin{array}{l}\text { A következó } 6 \text { hónapban nem szándékozom áttérni egy általam egészségesebbnek } \\
\text { vélt táplálkozásra. (I do not intend to change my old habits to an allegedly healthier } \\
\text { diet within the next } 6 \text { months.) }\end{array}$ & 7 & 10,4 \\
\hline $\begin{array}{l}\text { Erós késztetést érzek arra, hogy áttérjek egy általam egészségesebbnek vélt táplálko- } \\
\text { zásra. (I feel the need to switch to a diet considered healthier in my interpretation.) }\end{array}$ & 11 & 16,4 \\
\hline $\begin{array}{l}\text { A következó egy hónapban lépéseket fogok tenni, hogy átérjek egy általam egészsége- } \\
\text { sebbnek vélt táplálkozásra. (In the coming one month, I will take steps to switch to a } \\
\text { diet considered better in my interpretation.) }\end{array}$ & 11 \\
\hline $\begin{array}{l}\text { Már legalább } 6 \text { hónapja egészségesebben táplálkozok. (I have been eating healthier } \\
\text { for at least } 6 \text { months now.) }\end{array}$ & 4 \\
\hline $\begin{array}{l}\text { Már több mint } 6 \text { hónapja egészségesebben táplálkozok, a visszaesés esélye régi } \\
\text { táplálkozási szokásaimra minimális. (I have been following a healthier diet for more } \\
\text { than six months, the chance of relapse (return to my old habits) is minimal.) }\end{array}$ & 22 \\
\hline $\begin{array}{l}\text { Mindig is egészségesen táplálkoztam. (I have always been on a healthy diet.) } \\
\text { Forrás (Source): Saját szerkesztés (Authors' own compilation) }\end{array}$ & 12 \\
\hline
\end{tabular}

Forrás (Source): Saját szerkesztés (Authors'own compilation) 
Az egészséges táplálkozásra való áttérés szakaszai a döntően állati étrendet folytatók körében (Stages in the Transition to a Healthy Diet among those Predominantly on an Animal-based Diet) $(\mathrm{N}=\mathbf{2 5 0})$

\begin{tabular}{|c|c|c|}
\hline \multirow[t]{2}{*}{ Válaszkategóriák (Answer categories) } & \multicolumn{2}{|c|}{$\begin{array}{l}\text { Válaszok megoszlása } \\
\text { (Distribution of responses) }\end{array}$} \\
\hline & Fö (Count) & $\%$ \\
\hline $\begin{array}{l}\text { A következő } 6 \text { hónapban nem szándékozom áttérni egy általam egészségesebbnek } \\
\text { vélt táplálkozásra. (I do not intend to change my old habits to an allegedly healthier } \\
\text { diet within the next } 6 \text { months.) }\end{array}$ & 57 & 22,8 \\
\hline $\begin{array}{l}\text { Erős késztetést érzek arra, hogy áttérjek egy általam egészségesebbnek vélt táplálko- } \\
\text { zásra. (I feel the need to switch to a diet considered healthier in my interpretation.) }\end{array}$ & 57 & 22,8 \\
\hline $\begin{array}{l}\text { A következó egy hónapban lépéseket fogok tenni, hogy átérjek egy általam egészsége- } \\
\text { sebbnek vélt táplálkozásra. (In the coming one month, I will take steps to switch to a } \\
\text { diet considered better in my interpretation.) }\end{array}$ & 16 & 6,4 \\
\hline $\begin{array}{l}\text { Már legalább } 6 \text { hónapja egészségesebben táplálkozok. (I have been eating healthier } \\
\text { for at least } 6 \text { months now.) }\end{array}$ & 25 & 10,0 \\
\hline $\begin{array}{l}\text { Már több mint } 6 \text { hónapja egészségesebben táplálkozok, a visszaesés esélye régi } \\
\text { táplálkozási szokásaimra minimális. (I have been following a healthier diet for more } \\
\text { than six months, the chance of relapse (return to my old habits) is minimal.) }\end{array}$ & 33 & 13,2 \\
\hline Mindig is egészségesen táplálkoztam. (I have always been on a healthy diet.) & 62 & 24,8 \\
\hline
\end{tabular}

Az 5. táblázat adatait összehasonlítva a mindenevők csoportjával (6. táblázat) azt látjuk, hogy a döntően növényi ételeket fogyasztók kimagasló, 97\%-os arányban ismerték a vegetáriánus étrend fogalmát, 83,5\%-ban a vegánságot, ezt követően pedig 77,6\%-ban a laktovegetáriánusság fogalmát, ami a harmadik helyre került. A többihez képest kimagasló, kétharmadhoz közeli ismertsége volt a nyers vegánság fogalmának is. Míg az első két hely ugyanaz volt a két étrendi csoport körében, az ismertségi különbség a vegetáriánus és a vegán étrendek ismertsége között 20\%. Változott a harmadik és negyedik hely is, hiszen a mindenevőknél a laktovegetáriánus kategória csak a negyedik helyre volt elég közel 44\%-kal (szemben a vegetáriánusok 77,6\%-ával). Az Update étrend volt az egyetlen olyan kategória, amit többen ismertek a mindenevők (48,3\%), mint a vegetáriánusok $(38,8 \%)$. Összességében azonban elmondható, hogy az első két kategóriát és az Update étrendet leszámítva az összes többi kategória esetében 1,5-2,5-szer nagyobb arányban ismerték a különböző (döntően) növényi alapú étrendeket a vegetáriánusok, mint a mindenevők. 
A növényi alapú étrend-kategóriák ismertsége a döntően növényi eredetü étrendet folytatók körében (Awareness of Plant-based Diet Categories among those on a Predominantly Plant-based Diet) $(\mathrm{N}=67)$

\begin{tabular}{lcc}
\hline & Kategória (Category) & $\begin{array}{c}\text { Válaszok megoszlása } \\
\text { (Distribution of responses) }\end{array}$ \\
\cline { 2 - 3 } & Fó (Count) & $\mathbf{\%}$ \\
\hline Vegetáriánus (Vegetarian) & $\mathbf{6 5}$ & $\mathbf{9 7 , 0}$ \\
\hline Vegán (Vegan) & $\mathbf{5 6}$ & $\mathbf{8 3 , 5}$ \\
\hline Szemivegetáriánus (Semi-vegetarian) & 26 & 38,8 \\
\hline Ovovegetáriánus (Ovo-vegetarian) & 33 & 49,2 \\
\hline Laktoovovegetáriánus (Lacto-ovo-vegetarian) & 32 & 47,7 \\
\hline Fruitáriánus (Fruitarian) & 16 & 23,8 \\
\hline Laktovegetáriánus (Lacto-vegetarian) & $\mathbf{5 2}$ & 77,6 \\
\hline Nyers vegán (Raw vegan) & $\mathbf{4 1}$ & $\mathbf{6 1 , 1}$ \\
\hline Flexiteriánus (Flexitarian) & 9 & 13,4 \\
\hline Update étrend (Update diet) & 26 & 38,8 \\
\hline Etikai vegán (Ethical vegan) & 27 & 40,2 \\
\hline Ayurvéda táplálkozás (Ayurvedic diet) & 17 & 25,3 \\
\hline Makrobiotikus étrend (Macrobiotic diet) & 22 & 32,8 \\
\hline Forrás (Source): Saját szerkesztés (Authors'own compilation) & 2 \\
\hline
\end{tabular}

6. TÁBLÁZAT

TABLE 6

A növényi alapú étrend-kategóriák ismertsége a döntően állati eredetú étrendet folytatók körében (Awareness of Plant-based Diet Categories among those on a Predominantly Animal-based Diet) $(\mathrm{N}=\mathbf{2 5 0})$

\begin{tabular}{lcc}
\hline & \multicolumn{2}{c}{$\begin{array}{c}\text { Válaszok megoszlása } \\
\text { (Distribution of responses) }\end{array}$} \\
\cline { 2 - 3 } Vegetáriánus (Vegetarian) & Fó (Count) & $\mathbf{\%}$ \\
\hline Vegán (vegan) & $\mathbf{2 4 3}$ & $\mathbf{7 6 , 7}$ \\
\hline Szemivegetáriánus (Semi-vegetarian) & $\mathbf{2 2 1}$ & $\mathbf{6 9 , 7}$ \\
\hline Ovovegetáriánus (Ovo-vegetarian) & 60 & 18,9 \\
\hline Laktoovovegetáriánus (Lacto-ovo-vegetarian) & 80 & 25,2 \\
\hline Fruitáriánus (Fruitarian) & 78 & 24,6 \\
\hline Laktovegetáriánus (Lacto-vegetarian) & 61 & 19,2 \\
\hline Nyers vegán (Raw vegan) & $\mathbf{1 3 9}$ & $\mathbf{4 3 , 8}$ \\
\hline Flexiteriánus (Flexitarian) & $\mathbf{9 1}$ & $\mathbf{2 8 , 7}$ \\
\hline Update étrend (Update diet) & 17 & 5,4 \\
\hline Etikai vegán (Ethical vegan) & 153 & 48,3 \\
\hline Ayurvéda táplálkozás (Ayurvedic diet) & 53 & 16,7 \\
\hline Makrobiotikus étrend (Macrobiotic diet) & 42 & 13,2 \\
\hline Fortás (Source): Saját szkst & 45 & 14,2 \\
\hline
\end{tabular}

Forrás (Source): Saját szerkesztés (Authors'own compilation) 
A 7. táblázat a növényi étrend betartásának eltérő mértékét szemlélteti.

Arra a kérdésre, hogy a magukat vegetáriánusnak vallók mindig betartják-e az elviekben szigorú étrendjük szabályait, mintegy felük válaszolta azt, hogy általában igen. 16,4\%-uk határozottan betartja a szigorú szabályokat, mintegy harmaduk pedig nem tartotta problémának azt, ha egy vegetáriánus időnként „bünözik”, ettől még ugyanúgy megtarthatja identitását.

A női válaszadókra nagyobb arányban jellemző, hogy betartják a választott étrendet. Ha az igen és az általában igen kategóriákat együtt vizsgáljuk, megállapítható, hogy a nők nagyobb aránya tartja be az étrend követelményeit $(\mathrm{p}=0,033)$. Minél magasabb a válaszadók iskolai végzettsége, annál inkább jellemző rájuk, hogy betartják a választott étrendet $(\mathrm{p}=0,019)$. A nőtlen/hajadon válaszadók és a házastársuktól külön élők között nagyobb arányban jelen- nek meg azok, akik betartják az étrend elvárásait, mint a többi kategóriában $(\mathrm{p}=0,017)$.

A következő kérdés az volt, hogy a vegetáriánusok milyen aránya térne vissza a vegyes vagy döntően állati étrendre (8. táblázat).

A 8. táblázat világosan mutatja, hogy a minta vegetáriánus válaszadóinak kimagasló, 82\%-os többsége nem tartja elképzelhetőnek, hogy valaha is vissza- vagy áttérjen az állati eredetư és húsalapú táplálkozásra, ami azt jelenti, vegetáriánusok identitása szilárd alapokon nyugszik. Ezzel szemben 18\% azok aránya, akik bizonytalanok a növényi alapú identitásukban, és bizonyos körülmények hatására étrendet váltanának.

Mindkét nem esetében magas azok aránya, akik nem térnének vissza, vagy nem térnének át az állati eredetű étrendre $(\mathrm{p}=0,014)$. A többi háttérváltozó vonatkozásában nem volt szignifikáns kapcsolat.

7. TÁBLÁZAT

TABLE 7

A növényi étrendjüket szigorúan, kevésbé szigorúan vagy néha betartók megoszlása (Distribution of those who Adhere to their Plant-based Diet Strictly, Less Strictly, or Sometimes) (N=67)

\begin{tabular}{lcc}
\hline \multirow{2}{*}{$\begin{array}{c}\text { „Mindig betartja a növényi alapú étrend szabályait?" (“Do you always } \\
\text { follow the rules of a plant-based diet?”) }\end{array}$} & $\begin{array}{c}\text { Válaszok megoszlása } \\
\text { (Distribution of responses) }\end{array}$ \\
\cline { 2 - 4 } & Fó (Count) & \% \\
\hline Általában igen (Usually yes) & 34 & 50,7 \\
\hline Igen (Yes) & 11 & 16,4 \\
\hline Nem (No) & 22 & 32,8 \\
\hline
\end{tabular}

Forrás (Source): Saját szerkesztés (Authors'own compilation)

8. TÁBLÁZAT

TABLE 8

A vegetáriánusok vissza- vagy áttérési hajlandósága az állati étrendre (The Willingness of Vegetarians to Return or Switch to the Animal-based Diet) $(\mathrm{N}=67)$

\begin{tabular}{lcc}
\hline $\begin{array}{c}\text { „Vissza- vagy áttérne-e valamilyen okból az állati eredetü étrendre?”” } \\
\text { ("Would you return or switch to an animal-based diet for some } \\
\text { reasons?") }\end{array}$ & \multicolumn{2}{c}{$\begin{array}{c}\text { Válaszok megoszlása } \\
\text { (Distribution of responses) }\end{array}$} \\
\cline { 2 - 3 } & Fó (Count) & $\%$ \\
\hline Igen (Yes) & 12 & 17,9 \\
\hline Nem (No) & 55 & 82,1 \\
\hline
\end{tabular}

Forrás (Source): Saját szerkesztés (Authors'own compilation) 


\section{KÖVETKEZTETÉSEK ÉS JAVASLATOK - CONCLUSIONS AND PROPOSALS}

Cikkünk eredményeit nagyvonalakban vizsgálva kijelenthetjük, hogy a magyar fogyasztók - tartozzon a mindenevők vagy a növényi étrendet fogyasztók közé - általánosságban úgy észlelik, hogy a hagyományos, húsalapú étrendeknél egészségesebbek a reformkonyhába tartozó étrendek, élelmiszerek. Ezzel szemben áll az a probléma, hogy bár a vegetáriánusokat nagyon is, a mindenevőket kevésbé lehet ezen étrendek felé csalogatni pusztán az egészségességgel. Őket ugyanis nem igazán érdekli az egészségesség, amikor étrendet választanak. Viszont fontos számukra a teljes értékü étrend, és úgy gondolják, hogy nem laknának jól a csak növényi étrendektől. Emellett a növényi étrend felé való elmozdulás szélesebb teret nyerésének gátló tényezője lehet még annak észlelt költsége - zöldségektől és gyümölcsöktől függetlenül, mely kulcsfontosságú egy vegetáriánus étel összeállításánál. Továbbá kiderült még az is, hogy a növényi alapú étrendek felől nincs, az állati eredetúek felől viszont van átmenet a vegetáriánus étrendek felé.

A fentiekből kifolyólag a helyes stratégia az lenne, ha el tudnánk hitetni a többséggel, tehát az állati étrendet fogyasztókkal, hogy a növényi alapú étrenddel is elérhető a jóllakottság érzése, és a növényi alapú étrend is képes teljes tápanyagtartalmat biztosítani számukra, mindezt pedig megfizethető áron.

Cikkünk abból a szempontból egyedülálló, hogy talán mi alkalmaztuk először a viselkedésváltoztatási modellt (TTM) a vegetáriánus és a mindenevő fogyasztók összehasonlítása céljából. Ez alapján közvetett módon nem csak az a következtetés vonható le, hogy a vegetáriánusok egészségtudatosabbnak vélik magukat a mindenevőknél (56,6\%), hanem a két-két étrendi kategóriára lebontva is képesek lehetünk elhatárolni egymástól a fogyasztók viselkedését. A mindenevők körében az egészségesebb táplálkozás felé való elmozdulás is jóval alacsonyabb: közel negyedük, míg a növényi csoport mindössze tizede vallotta, hogy nem tervez elmozdulni egy egészségesebb táplálkozási alternatíva irányába. De a mindenevők körében kevesebben voltak azok is, akik tervezik vagy készek változtatni jelenlegi (azaz a közvélekedés szerint kevésbé egészséges) étrendjükön, szemben a vegetáriánus csoporttal $(29,2 \%$ vs. $32,8 \%)$. Ez esetben az utóbbi csoportba nagyobb valószínűséggel tartozhatnak a „döntően növényi étrendet követők", azaz a nem teljes egészében vegetáriánusok, akiknek még van hova „fejlődniük”. Az első csoportot pedig nagyobb arányban alkothatják a „teljes mértékben állati étrendet követők”, akiknek ebből kifolyólag kevésbé változatos az étrendjük. Így tehát egy fejlődési pálya rajzolódik ki előttünk: az egészségtudatosság szintje alulról felfelé halad: a teljes mértékben állati eredetű élelmiszereket fogyasztóktól (akik kevésbé gondolják egészségesnek étrendjüket) a teljes mértékben növényi ételeket fogyasztók felé (akik viszont úgy érzik, elérték egészségcéljaikat).

Következtetéseinket és a kapott eredményeket figyelembe véve, a következő javaslatokat tesszük a növényi alapú étrendre történő átváltás érdekében:

- mivel a vegetáriánusok és a mindenevók motivációi teljesen mások, ezért differenciált kommunikációs stratégia javasolt: előbbiek esetében elsősorban a testi-lelki egészséget, a jobb közérzetet, míg az utóbbi csoportnál a megfizethető árat, a megfelelő tápanyagtartalmat és az étel tápláló jellegét érdemes első helyen kihangsúlyozni;

- a Transzteoretikus modellre alapozva láthatjuk, hogy a mindenevők között is szép számmal vannak, akik hajlandóak lennének elmozdulni egy egészségesebb étrendi alternatíva irányába. Ebből következően ebben a szegmensben vélhetően sikerrel kommunikálható az egészségesség szempontja;

- a növényi alapú étrendi kategóriák ismertsége alapján pedig a promóciós stratégiát érdemes differenciálni mindkét csoportra: a kevésbé ismert étrendeket intenzívebb, míg a jól ismert kategóriákat kevésbé intenzív reklámozással. Azokban a szegmensekben pedig, amelyek potenciálisan jól ismerhetik a legtöbb kategóriát (például a született vegetáriánusok), megjelenhet a változatosságot kereső magatartás, így tehát köreikben sikerrel nép- 
szerüsíthetők a legkevésbé ismert étrendek is, hisz az újdonság ereje hajtja őket;

- a vegetáriánusok egyharmada jelezte, hogy nem követi annyira szigorúan a vegetáriánus étrendet, ezért az ő körükben inkább a flexiteriánus étrend promóciója vihető sikerre.

\section{5. ÖSSZEFOGLALÁS - SUMMARY}

Századunk és napjaink megkerülhetetlen problémájává váltak a nem fertőző, krónikus betegségek, melyek megjelenésének hatására az emberiség, azon belül a különböző társadalmak megoldást kívántak találni az újfajta betegségtípusokra. Miután megállapítást nyert, hogy helyes táplálkozással csökkenthetők vagy elkerülhetők a krónikus betegségek, az emberek alternatív táplálkozási módok (köznépi nyelven reformkonyha) felé fordultak, melynek eredményeként számos alternatív étrend jelent meg, közülük is minden bizonnyal a növényi alapú táplálkozási módok a legelterjedtebbek. Az elmúlt évek, évtizedek során egyre trendibb lett egészségtudatosan élni és táplálkozni. A dolgok azonban idővel megváltoztak, az egészségtudatos fogyasztói magatartásból világ(mega-) trend lett.

Bár azt nem jelenthetjük ki megkérdőjelezhetetlenül, hogy a növényi alapú táplálkozási módok az egészségtudatosság zászlóvivői, de érdemes tudni, mit gondolnak erről a normál étrendet folytató, de főleg maguk a vegetáriánus fogyasztók.

Kutatásunkból kiderült, hogy a vegetáriánus fogyasztók számára a két legfontosabb érv étrendjük mellett a jobb közérzet megteremtése, illetve az egészségmegőrzés. Ez tehát arra utal, hogy a növényi étrendek fogyasztói számára a testi-lelki egészség kulcsfontosságú, az ilyen típusú étrendeket követők meg vannak győződve egészségtudatosságuk magas szintjéről. Érdekesség viszont, hogy míg a szakirodalom egy része két fő vegetáriánus kategóriát különített el (etikai és egészségvegetáriánusok), a mi kutatásunk ezt nem igazolta vissza, hiszen az állatokkal való együttérzés az utolsó szempontok egyike lett (4,6\%).
A növényi alapú táplálkozást az egészségtudatossággal összekötő feltételezést erősítette a Transzteoretikus Modell is: míg a vegetáriánusok kicsit több mint fele, addig a mindenevők kicsit több mint harmada gondolja úgy, hogy már legalább fél éve, vagy mindig is egészségesen táplálkozott. Emellett az első csoport körében többen voltak azok is, akik erős késztetést éreznek egy általuk egészségesebbnek vélt táplálkozási mód felé történő elmozdulásra. Ez arra utal, hogy a jelenlegi étrendjüket nem tartják az egészségesség szempontjából a legkedvezőbbnek. Azt pedig említenünk sem kell, hogy a növényi alapú étrendek ismertsége rendre sokkal magasabb volt a vegetáriánusok körében. Az iskolai végzettség is összefüggésben áll a növényi étrend szigorú vagy általános betartásával. Kutatásunkból kiderült továbbá az is, hogy a növényi étrendet fogyasztók nagyon magas arányban (82\%) érzik úgy, hogy étrendjükkel megtalálták a számításaikat.

\section{IRODALOMJEGYZÉK - REFERENCES}

Bechthold, A. - Boeing, H. Schwedhelm, C. - Hoffmann, G. Knüppel, S. - Iqbal, K. - De Henauw, S. - Michels, N. - Devleesschauwer, B. - Schlesinger, S. - Schwingshackl, L.: Food Groups and Risk of Coronary Heart Disease, Stroke and Heart Failure: A Systematic Review and Dose-Response Meta-Analysis of Prospective Studies. Critical Reviews in Food Science and Nutrition. 2019. 59 (7) 1071-1090. DOI: https://doi.org/10.1080/10408398.2017. 1392288

Cena, H. - Calder, P. C.: Defining a Healthy Diet: Evidence for the Role of Contemporary Dietary Patterns in Health and Disease. Nutrients. 2020. 12 (2) 1-15. DOI: https://doi.org/10.3390/ nu12020334

Dagevos, J. C. - Gaasbeek, A. F.: Approching Contemporary Food Consumers: A few Reflections on Research and Results. 71st EAAE Seminar - The Food Consumer in the Early 21st Century. Zaragoza, April 19-20, 2001. 
Fox, N. J. - Ward, K. J.: Health, Ethics and Environment: A Qualitative Study of Vegetarian Motivations. Appetite. 2008. 50 (2-3) 422-429. DOI: https://doi. org/10.1016/j.appet.2007.09.007

Fuglestad, P. T. - Rothman, A. J. Jeffery, R. W. - Sherwood, N. E.: Regulatory Focus, Proximity to Goal Weight, and Weight Loss Maintenance. American Journal of Health Behaviour. 2015. 39 (5) 709-720. DOI: https://doi. org/10.5993/ajhb.39.5.12

Fehér, A. - Gazdecki, M. - Véha, M. - Szakály, M. Z. - Szakály, Z.: A Comprehensive Review of the Benefits of and the Barriers to the Switch to a Plant-Based Diet. Sustainability. 2020. 12 (10) Paper: 4136. DOI: https://doi. org/10.3390/su12104136

GFK: Trenddé alakulni látszik az egészségtudatosság. 2016. URL: http:// www.gfk.com/hu/insightok/pressrelease/gfk-trendde-alakulni-latszik-azegeszsegtudatossag/ (Letöltés dátuma: 2020.12.10.)

Heinrich Böll Stiftung.: Facts and Figures About the Animals We Eat. Meat Atlas. Berlin, 2014.

Hoffman, S. R. - Stallings, S. F. Bessinger, R. C. - Brooks, G. T.: Differences Between Health and Ethical Vegetarians. Strength of Conviction, Nutrition Knowledge, Dietary Restriction, and Duration of Adherence. Appetite. 2013. 65 139-144. DOI: https://doi. org/10.1016/j.appet.2013.02.009

Hornsey, M. J. - Jetten, J.: Not Being What You Claim to Be: Impostors as Sources of Group Threat. European Journal of Social Psychology. 2003. 33 (5) 639-657. DOI: https://doi.org/10.1002/ejsp.176

Jabs, J. - Devine, C. - Sobal, J.: Model of the Process of Adopting Diets: Health Vegetarians and Ethical Vegetarians. Journal of Nutrition Education. 1998. 30 (4) 196-202. DOI: https://doi. org/10.1016/Soo22-3182(98)70319-X

Key, T. J. - Allen, N. E. - Spencer, E. A. - Travis, R. C.: Evidence for Diet as a Risk Factor for Cancer. Lancet. 2002. 360 861-868. DOI: https://doi.org/10.1016/ So140-6736(02)09958-O
Lavie, C. J. - Milani, R. V. - Ventura, H. O.: Obesity and Cardiovascular Disease: Risk Factor, Paradox, and Impact of Weight Loss. Journal of the American College of Cardiology. 2009. 53 (21) 19251932. DOI: https://doi.org/10.1016/j. jacc.2008.12.068

Leahy, E. - Lyonsa, S. - Tol, R.: An Estimate of the Number of Vegetarians in the World. The Economic and Social Research Institute. 2010. No. 340.

Leitzmann, C.: Vegetarian Nutrition: Past, Present, Future. The American Journal of Clinical Nutrition. 2014. 100 (1) 496502. DOI: https://doi.org/10.3945/ ajen.113.071365

Melina, V. - Craig, W. - Levin, S.: Position of the Academy of Nutrition and Dietetics: Vegetarian Diets. Journal of the Academy of Nutrition and Dietetics. 2016. 116 19701980. DOI: https://doi.org/10.1016/j. jand.2016.09.025

National Nutrition Monitoring Bureau: Diet and Nutrition Status of Population and Prevalence of Hypertension among Adults in Rural Areas. National Institute of Nutrition, Indian Council of Medical Research. Technical Report No. 24. 2006. Hyderabad, India, 64 (79)

National Nutrition Monitoring Bureau: Report of Urban Survey-Slums. National Institute of Nutrition, Indian Council of Medical Research. Technical Report No. 15. 1994 .

Nezlek, J. B. - Forestell, C. A.: Vegetarianism as a Social Identity. Current Opinion in Food Science. 2020. 33 45-51. DOI: https://doi.org/10.1016/j. cofs.2019.12.005

Plante, C. N. - Rosenfeld, D. L. - Plante, M. - Reysen, S.: The Role of Social Identity Motivation in Dietary Attitudes and Behaviors Among Vegetarians. Appetite. 2019. 141 104307. DOI: https:// doi.org/10.1016/j.appet.2019.05.038

Rosenfeld, D. L.: The Psychology of Vegetarianism: Recent Advances and Future Directions. Appetite. 2018. 131 125-138. DOI: https://doi.org/10.1016/j. appet.2018.09.011 
Rosenfeld, D. L. - Burrow, A. L.: The Unified Model of Vegetarian Identity: A Conceptual Framework for Understanding Plant-Based Food Choices. Appetite. 2017. 112 78-95. DOI: https://doi.org/10.1016/j. appet.2017.01.017

Rothgerber, H.: Attitudes Toward Meat and Plants in Vegetarians. (In: F. Mariotti). Academic Press, London, 2017. DOI: https://doi.org/10.1016/B978-0-12803968-7.00002-2

Ruby, M. B.: Vegetarianism. A Blossoming Field of Study. Appetite. 2012. 58 141150. DOI: https://doi.org/10.1016/j. appet.2011.09.019

Rützler, H. - Kirig, A.: Food-styles. pp. 51-86. Zukunftsinstitut, Bonn, 2007. Shepherd, R.: The Psychology of Food Choice. Nutrition \& Food Science. 1990. 90 (3) $2-4$.

Törőcsik, M.: Food-trendek és trendi vásárlói csoportok. Acta Oeconomica Kaposváriensis. 2011. (1) 1-2.
Véha, M. - Szakály, Z. - Fehér, A.: A növényi alapú étrendet hátráltató tényezők rendszerezése - Szakirodalmi áttekintés. In: Fehér, A. - Szakály, Z. (szerk.): Egészségpiaci kutatások Debrecen, Magyarország: Debreceni Egyetem Gazdaságtudományi Kar, 2019a. 105-112.

Véha, M. - Szakály, Z. - Fehér, A.: A növényi alapú étrendet támogató tényezők rendszerezése - Szakirodalmi áttekintés. In: Fehér, A. - Szakály, Z. (szerk.): Egészségpiaci kutatások Debrecen, Magyarország: Debreceni Egyetem Gazdaságtudományi Kar. 2019b. 95-104.

Vossen, K. - Reinhardt, A. F.: Zukunftsmärkte - Was das Marketing über Kunden der Zukunft wissen sollte. Metropolitan Verlag, Düsseldorf, Berlin, 2002.

Wier, M. - Calverly, C.: Market Potential for Organic Foods in Europe. British Food Journal. 2002.104(1) 45-62. DOI: https:// doi.org/10.1108/00070700210418749

\section{JEGYZETEK $\Vdash$ NOTES}

